\title{
NUTRITONAL EVALUATION OF PEMPHIGUS FOLIACEUS PATIENTS ON LONG TERM GLUCOCORTICOID THERAPY
}

\author{
Daniel Ferreira da CUNHA, Selma Freire de Carvalho da CUNHA, Jacqueline Pontes MONTEIRO, Tácio Pierre Souza FERREIRA, Jenner Arruda Modesto dos SANTOS,
} Rogério Abrão FURTADO, Rosana Silva MARSSARO, Ruti Aparecida MUNIZ \& Roseli Aparecida da Silva GOMES

\begin{abstract}
SUMMARY
Our objective was to compare food intake and nutritional status of Pemphigus Foliaceus patients (PG) on long term glucocorticoid therapy to a Control Group (CG). Fourteen PG female inpatients receiving prednisone $(0.33 \pm 0.22 \mathrm{mg} / \mathrm{kg})$ for at least $12 \mathrm{months}$ and twelve CG subjects were submitted to nutritional evaluation, including anthropometry, urinary creatinine determination and serum biochemical measurements, besides 48-h-based food intake records. Groups were compared by Chi-square, Mann-Whitney and " $\mathrm{t}$ " tests. PG patients and CG were paired, respectively, in relation to age ( $24.7 \pm 14.1 \mathrm{vs.} 22.0 \pm 12.0$ years), body mass index ( $25.8 \pm 6.4$ vs. $\left.24.0 \pm 5.6 \mathrm{~kg} / \mathrm{m}^{2}\right)$, daily protein intake $(132.9 \pm 49.8 \mathrm{vs} .95 .2 \pm 58.9 \mathrm{~g})$, and serum albumin (median; range) $(3.8 ; 3.5-4.1 \mathrm{vs} .3 .8$; $3.6-5.0 \mathrm{~g} / \mathrm{dl})$. However, PG patients had lower height-creatinine index $(64.8 \pm 17.6 \mathrm{vs.} 90.1 \pm 33.4 \%)$, and higher daily energy (3080 \pm 1099 vs. $2187 \pm 702 \mathrm{kcal})$ and carbohydrate $(376.8 \pm 135.8$ vs. $242.0 \pm 80.7 \mathrm{~g})$ intakes. Despite high food, protein and energy consumption, PG patients on long term glucocorticoid therapy had lower body muscle mass than controls, while showing high body fat stores. These findings are possibly related to combined metabolic effects of long term corticotherapy and inflammatory disease plus corticosteroid-induced increased appetite.
\end{abstract}

KEYWORDS: Pemphigus foliaceus; Glucocorticoid therapy; Nutritional status.

\section{INTRODUCTION}

Endemic pemphigus foliaceus (wild fire, or fogo selvagem) is a chronic autoimmune disease histologically characterized by acantholysis and blister formation within the epidermis ${ }^{5,16,20}$. Pemphigus foliaceus is endemic in certain regions of Brazil and is characterized by circulating and skin antibodies (IgG4 subclass) against desmosomal-associated antigens (desmoglein-1), which results in local inflammatory reaction and loss of the cohesion of keratinocytes ${ }^{7}$. In its severe, generalized, life-threatening form there are scalp, face, trunk and limbs skin involvement, which demands chronic glucocorticoids administration to control disease ${ }^{14,16}$.

Despite possible nutritional depletion that can result from the generalized blisters formation and widespread skin exfoliation, no references to nutritional evaluation on pemphigus foliaceus are available in the literature, except a recent one which concludes that untreated pemphigus foliaceus patients presented signs and symptoms of protein, but not energy malnutrition ${ }^{1}$.

To our knowledge there are no specific study describing the nutritional status of a more common condition, where a stable pemphigus foliaceus patient is receiving chronic corticotherapy, a situation where opposite factors that can affect nutritional status occurs, namely, hypercatabolic and hypermetabolic effects of a chronic inflammatory disease, and prolonged corticosteroids use, which also has catabolic consequences, while increasing appetite and food consumption ${ }^{2}$.

The aim of the present study was to compare the nutritional status (by anthropometry and biochemical parameters, besides food intake records) of pemphigus foliaceus patients on long term glucocorticoid therapy to a control group.

\section{MATERIAL AND METHODS}

The study was performed according to the Declaration of Helsinki and all procedures were explained to participants before obtaining their informed consent. Fourteen female patients with endemic pemphigus foliaceus (PG, Pemphigus Group) participated in the study. They were hospitalized at Fogo Selvagem Hospital of Uberaba-MG, Brazil, a philanthropical institution where patients, most of them coming from distant rural areas, abide for long periods while receiving treatment. The Control Group ( $\mathrm{CG}, \mathrm{n}=12$ ) was composed of healthy female persons paired for age and similar social, physical and constitutional characteristics. All volunteers were submitted to clinical examination, including blood pressure measurements, which was performed in accordance with World Health Organization standards ${ }^{19}$. 


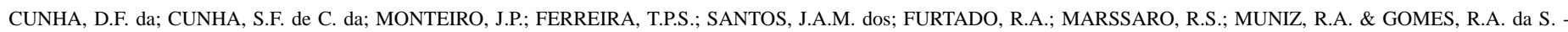
Nutritonal evaluation of pemphigus foliaceus patients on long term glucocorticoid therapy. Rev. Inst. Med. trop. S. Paulo, 42 (1): $23-26,2000$.

Pemphigus foliaceus was diagnosed on the basis of epidemiological data, clinical signs and symptoms, and skin histopathological examination. All patients presented the generalized form of the disease $\mathrm{e}^{1,6}$, with skin involvement of the scalp, face, trunk and limbs. None of them had history of diabetes mellitus, high blood pressure, diarrhea, malabsorption, or renal insufficiency, or current signs or symptoms of acute infections. All patients were receiving immunosuppressive oral dosage of prednisone $(0.33 \pm 0.22 \mathrm{mg} / \mathrm{kg}$ of body weight $)$ for at least 12 months (median $=22$, range 12 to 112 months). No PG patient was on adjunctive immunosuppressive therapy, and two were taking phenobarbital. None of the volunteers was enrolled in regimens or taking drugs affecting appetite.

Anthropometric evaluation was carried out by measuring weight, height, arm circumference and triceps skin fold. Height was measured, without shoes, to the nearest $0.1 \mathrm{~cm}$ by using an inextensible tape. Weight was measured in the morning, in the fasted state, after voiding and without clothing and shoes, to the nearest $0.1 \mathrm{~kg}$ by using portable scales. Triceps skin fold was measured on the non-dominant arm using a Holtain ${ }^{\circledR}$ skinfold caliper (Crymych, U.K.) after measuring a point halfway down the arm, between the scapula acromion and the ulna olecranon. Body mass index (BMI) was defined as weight in kilograms divided by height in squared meters $\left(\mathrm{kg} / \mathrm{m}^{2}\right)$; BMI $>25 \mathrm{~kg} / \mathrm{m}^{2}$ was used as criterion of overweight or obesity ${ }^{10}$.

Dietary intake data for two consecutive days during the week was registered from all patients and controls. Basically, both PG and CG groups consumed a diet based on typical rice and beans admixture, plus fruits, vegetables and some meat, five to sixfold a day. To accurately estimate the quantities of consumed nutrients, kitchen utensils (plates, glasses, and spoons) and containers of known capacity were used. The methods of food preparation were also known by a registered dietitian, which calculated the intake of energy, proteins, lipids, carbohydrates, sodium, calcium, phosphorus, magnesium, and potassium, by using a PC computer program. The food tables used in the program are from the U.S. Department of Agriculture, Handbook \# 8, 1980, with some regional foods added ${ }^{12}$.

Table 1

Anthropometric and laboratorial parameters in control persons and pemphigus foliaceus patients on long term glucocorticoid therapy at Fogo Selvagem Hospital of Uberaba-MG, Brazil

\begin{tabular}{lcc}
\hline Parameters & Pemphigus & Controls \\
\hline Weight $(\mathrm{kg})$ & $57.2 \pm 13.7$ & $57.6 \pm 15.5$ \\
Height $(\mathrm{cm})$ & $147.5 \pm 0.12$ & $154.3 \pm 0.07$ \\
Body mass index $\left(\mathrm{kg} / \mathrm{m}^{2}\right)$ & $25.84 \pm 6.38$ & $24.03 \pm 5.6$ \\
Arm circumference $(\mathrm{cm})$ & $28.6 \pm 4.5$ & $27.3 \pm 4.0$ \\
Triceps skinfold $(\mathrm{mm})$ & $23.8 \pm 7.1$ & $25.3 \pm 9.5$ \\
Serum total proteins $(\mathrm{g} / \mathrm{dl})$ & $7.05 \pm 0.45$ & $7.12 \pm 0.50$ \\
Serum albumin $(\mathrm{g} / \mathrm{dl})$ & $3.8(3.5-4.1)$ & $3.8(3.6-5.0)$ \\
Hemoglobin $(\mathrm{g} / \mathrm{dl})$ & $13.1 \pm 1.3$ & $13.7 \pm 0.9$ \\
Erythrocyte sedimentation* & $44(9-87)$ & $8(2-30)$ \\
Height-creatinine index $(\%)^{*}$ & $64.8 \pm 17.6$ & $90.1 \pm 23.4$ \\
\hline
\end{tabular}

$* \mathrm{p}<0.05$
Energy intake percentage was calculated according to the formula: actual energy intake x 100/basal energy expenditure, determined by Harris-Benedict formula ${ }^{13}$. All hospitalized patients were able to stand up and walk around at a hospital outdoor area set aside for recreation; most of them were engaged in diurnal light activities, such as watching $\mathrm{TV}$ or playing cards or domino. CG persons were engaged in free-living daily light physical activities.

Fasting blood was collected from a peripheral vein of each patient and control subject for serum sodium, potassium, calcium, urea, albumin and total protein measurements, in addition to hemoglobin and erythrocyte sedimentation rate (ESR) determinations. Creatinine excreted in urine during 48 hours, which correlates with body muscle mass ${ }^{9,18}$, was measured and the results expressed in $\mathrm{mg} /$ day, on a $24-\mathrm{h}$ basis, the same occurring with urinary urea excretion.

Continuous variables with normal distribution are expressed as mean \pm standard deviation; in this case the comparison between groups were performed using the " $t$ " Student test. Mann-Whitney test was used for variables with non-normal distribution, which are expressed as median and range. The Fisher exact test was used to compare frequency distributions between groups. A p value $<0.05$ was considered statistically significant.

\section{RESULTS}

PG patients and CG persons were paired, respectively, in relation to age $(24.7 \pm 14.1$ vs. $22.0 \pm 12.0$ years $)$, ethnic origin, with non-white color predominance (66.7 vs. $57.2 \%$ ), height (147.5 \pm 0.12 vs. $154.3 \pm$ $0.07 \mathrm{~cm})$, body mass index $\left(25.8 \pm 6.4\right.$ vs. $\left.24.0 \pm 5.6 \mathrm{~kg} / \mathrm{m}^{2}\right)$, and other anthropometric measurements (Table 1).

Overweight or obesity was diagnosed in five PG patients (42\%) and seven $(50 \%)$ CG persons. Despite similar diastolic blood pressure between PG $(74.6 \pm 12.8 \mathrm{mmHg})$ and $\mathrm{CG}(71.2 \pm 6.4 \mathrm{mmHg})$ groups, pemphigus foliaceus patients showed higher systolic blood pressure (123.2 \pm 18.9 vs. $108.7 \pm 8.3 \mathrm{mmHg})$ and heart rate $(90.1 \pm 16.1$ vs. $75.4 \pm 5.8 \mathrm{bpm})$.

Table 2

Daily dietary intake of controls subjects and pemphigus foliaceus patients on long term glucocorticoid therapy at Fogo Selvagem Hospital of Uberaba-MG, Brazil

\begin{tabular}{lcc}
\hline Parameters & Pemphigus & Controls \\
\hline Energy $(\mathrm{kcal}) *$ & $3079.97 \pm 1099.6$ & $2187.3 \pm 701.8$ \\
Energy $(\%$ of BMR)* & $231.87 \pm 80.46$ & $163.86 \pm 59.87$ \\
Protein $(\mathrm{g})$ & $132.95 \pm 49.82$ & $95.16 \pm 28.1$ \\
Lipids $(\mathrm{g})$ & $114.42 \pm 40.52$ & $93.56 \pm 28.1$ \\
Carbohydrates $(\mathrm{g}) *$ & $376.83 \pm 135.8$ & $242.04 \pm 80.75$ \\
Calcium (mg) & $1202.4 \pm 443.8$ & $834.87 \pm 321.5$ \\
Sodium $(\mathrm{mg})$ & $2702.71 \pm 994.8$ & $2331.66 \pm 880.3$ \\
Potassium $(\mathrm{mg})$ & $3645.5 \pm 1551.7$ & $3787.0 \pm 1593.0$ \\
Phosphorus $(\mathrm{mg})$ & $1820.1 \pm 695.9$ & $1350.3 \pm 714.1$ \\
Magnesium $(\mathrm{mg})$ & $111.6 \pm 43.7$ & $133.9 \pm 71.9$ \\
\hline
\end{tabular}

$\mathrm{BMR}=$ basal metabolic rate, determined by Harris-Benedict formula; $* \mathrm{p}<0.05$ 
PG and CG groups showed similar blood hemoglobin $(13.1 \pm 1.3$ vs. $13.7 \pm 0.9 \mathrm{~g} / \mathrm{dl})$, and serum total proteins $(7.05 \pm 0.45$ vs. $7.12 \pm$ $0.50 \mathrm{~g} / \mathrm{dl})$, albumin (median; range) $(3.8 ; 3.5-41$ vs. $3.8 ; 3.6-5.0 \mathrm{~g} / \mathrm{dl})$, urea $(21.5 \pm 9.3$ vs. $22.3 \pm 7.1 \mathrm{mg} / \mathrm{dl})$, and calcium $(8.5 \pm 0.6$ vs. $8.6 \pm$ $1.0 \mathrm{mg} / \mathrm{dl})$. Despite higher serum sodium $(140.9 \pm 1.6$ vs. $139.3 \pm$ $1.9 \mathrm{mEq} / \mathrm{l})$ and erythrocyte sedimentation rate $(44 ; 9-87$ vs. $8 ; 2-30), \mathrm{PG}$ patients had lower values of serum potassium $(3.21 \pm 0.69$ vs. $3.73 \pm$ $0.26 \mathrm{mEq} / \mathrm{l})$ and height-creatinine index $(64.8 \pm 17.6$ vs. $90.1 \pm 33.4 \%)$. CG and PG showed similar urinary urea excretion, respectively $13.4 \pm$ 3.7 and $11.4 \pm 3.4 \mathrm{~g} /$ day.

PG patients ingested greater daily amount of food (Table 2), as documented by higher energy consumption (3079.9 \pm 1099.6 vs. 2187.3 $\pm 701.8 \mathrm{kcal})$, carbohydrate $(376.8 \pm 135.8$ vs. $242.0 \pm 80.7 \mathrm{~g})$ and calcium $(1202.4 \pm 443.8$ vs. $834.9 \pm 321.5 \mathrm{~g})$. Sodium, potassium, phosphorus and magnesium intakes were similar between groups (Table 2).

\section{DISCUSSION}

Notwithstanding similar demographic and anthropometric characteristics, and higher energy, carbohydrate, calcium, and other food constituent's intake, pemphigus foliaceus patients on long term glucocorticoid therapy showed lower values of height-creatinine index than controls. As urinary creatinine determination is a well grounded method of muscle mass measurement ${ }^{10,18}$, one can conclude that, despite above average triceps skin fold documenting increased body fat reserves ${ }^{9}$, these patients also have decreased body skeletal muscle. Our findings suggest that these differences can not be attributed to insufficient protein intake or to increased losses of urinary nitrogen. Rather, as all patients had pemphigus foliaceus generalized form, it is possible that increased protein losses associated with skin cell desquamation might have such effect in body protein status.

Normal serum albumin levels of our cases differ from those of BARRAVIERA et al., which documented hypoalbuminemia in patients with disseminated form of pemphigus foliaceus ${ }^{1}$. Nonetheless, serum albumin is not a good nutritional index in chronic inflammation, because serum albumin levels are largely determined by nonnutritional factors such as cytokine-induced reprioritization of hepatic protein synthesis, catabolism, dilution, and third-space $\operatorname{losses}^{13}$. In addition, besides a possible role of increased hepatic albumin synthesis induced by corticosteroids $^{1,8}$, normal serum albumin levels in our PG patients can be ascribed to high protein and energy intake.

Calcium intake of most PG patients was adequate to meet normal person's requirements. However, as supraphysiological concentrations of glucocorticoids inhibit bone formation and reduce intestinal calcium absorption, these patients may be under increased risk of osteoporosis ${ }^{4}$. In addition, according to hypercortisolism state, and despite similar sodium and potassium intakes, pemphigus patients showed higher sodium and lower potassium serum levels.

Decreased physical activity often occurs in chronic ill patients ${ }^{15}$ and, as documented in the present study, long term glucocorticoid therapy is associated with high energy intake, which could predispose PG patients to complications such as obesity and glucose intolerance. Moreover, oral cortisol increases blood pressure in a dose-dependent fashion, phenomenon accompanied by a significant sodium retention and volume expansion $^{3}$. Indeed, PG patients showed higher systolic blood pressure than controls. Nonetheless, despite increased body mass index in PG patients might be ascribed to increased energy consumption and decreased physical activity, high overweight and obesity frequencies in control group is not apparent and could be attributed to low social rank, where obesity prevalence is raising, or to some unidentifiable bias in control group choice.

Prolonged systemic high corticosteroids administration is crucial for pemphigus control, but it is often associated with numerous side effects $^{2,11}$, including increased body fat accumulation and decreased muscle mass ${ }^{17}$. Therefore, the present study showed that, despite high food, protein and energy consumption, pemphigus foliaceus patients on long term glucocorticoid therapy had lower body muscle mass than controls, while showing high body fat stores. These findings are possibly related to combined metabolic effects of chronic corticotherapy and inflammatory disease plus corticosteroid-induced increased appetite, besides decreased physical activity. A rational diet therapy approach would be to prescribe high-protein, low fat, low sodium and low carbohydrates diets, with attention paid to calcium and potassium levels.

\section{RESUMO}

\section{Avaliação do estado nutricional de pacientes com pênfigo foliáceo sob corticoterapia prolongada}

O objetivo deste trabalho foi comparar o estado nutricional e dados de ingestão alimentar de pacientes com Pênfigo Foliáceo (PF, n=14) sob corticoterapia prolongada (prednisona, $0,33 \pm 0,22 \mathrm{mg} / \mathrm{kg} / \mathrm{dia}$ há mais de 12 meses) com um Grupo Controle (GC, n=12). A avaliação constou de inquérito alimentar de 48 horas, antropometria e determinação de creatinina urinária de $24 \mathrm{~h}$ e albumina sérica. Os grupos PF e GC foram pareados, respectivamente, quanto à idade $(24,7 \pm 14,1$ vs $22,0 \pm 12,0$ anos), índice de massa corporal (25,8 $\pm 6,4$ vs $\left.24,0 \pm 5,6 \mathrm{~kg} / \mathrm{m}^{2}\right)$, ingestão diária de proteína $(132,9 \pm 49,8$ vs 95,2 $\pm 58,9 \mathrm{~g})$ e albumina sérica (mediana;faixa de variação) $(3,8 ; 3,5-4,1$ vs 3,8;3,6-5,0g/dl). Pacientes com pênfigo apresentaram menor índice creatinina-altura $(64,8 \pm 17,6$ $v s 90,1 \pm 33,4 \%)$ e maior ingestão de energia (3080 \pm 1099 vs $2187 \pm$ $702 \mathrm{kcal} / \mathrm{dia})$ e carboidratos (376,8 $\pm 135,8$ vs 242,0 $\pm 80,7 \mathrm{~g} / \mathrm{dia})$. Apesar do maior consumo de alimentos, os pacientes com pênfigo apresentaram menor massa muscular que os controles, achados possivelmente relacionados ao aumento do apetite e efeitos metabólicos combinados da corticoterapia e da doença inflamatória crônica.

\section{REFERENCES}

1. BARRAVIERA, S.R.C.S.; DILLON, N.L.; CURI, P.R.; PEREIRA, P.C. \& ALMEIDA, D.B. - Evaluation of nutritional status in patients with endemic pemphigus foliaceus. Rev. Inst. Med. trop. S. Paulo, 37: 51-58, 1995.

2. BOUMPAS, D.T.; CHROUSOS, G.P.; WILDER, R.L.; CUPPS, T.R. \& BALOW, J.E. Glucocorticoid therapy for immune-mediated diseases: basic and clinical correlates. Ann. intern. Med., 119: 1198-1208, 1993.

3. BYSTRYN, J.C. \& STEINMAN, N.M. - The adjuvant therapy of pemphigus. An update Arch. Derm., 132: 203-212, 1996.

4. COMPSTON, J.E. - Management of bone disease in patients on long term glucocorticoid therapy. Gut, 44: 770-772, 1999. 
CUNHA, D.F. da; CUNHA, S.F. de C. da; MONTEIRO, J.P.; FERREIRA, T.P.S.; SANTOS, J.A.M. dos; FURTADO, R.A.; MARSSARO, R.S.; MUNIZ, R.A. \& GOMES, R.A. da S. Nutritonal evaluation of pemphigus foliaceus patients on long term glucocorticoid therapy. Rev. Inst. Med. trop. S. Paulo, 42 (1): 23-26, 2000.

5. EVERSOLE, L.R. - Immunopathology of oral mucosal ulcerative, desquamative, and bullous diseases. Selective review of the literature. Oral Surg. Oral Med. Oral Path., 77: 555-571, 1994.

6. FRIEDMAN, H.; CAMPBELL, I.; ROCHA-ALVAREZ, R. et al. - Imunofluorescência indireta no pênfigo foliáceo endêmico. Contribuição para sua padronização. Rev. Inst. Med. trop. S. Paulo, 31: 158-168, 1989.

7. FRIEDMAN, H.; CAMPBELL, I.; ROCHA-ALVAREZ R. et al. - Endemic pemphigus foliaceus (fogo selvagem) in native Americans from Brazil. J. Amer. Acad. Derm., 32: 949-956, 1995.

8. GROSSMAN, J.; YALOW, A.A. \& WESTON, R.E. - Albumin degradation and synthesis as influenced by hydrocortisone, cortrophin and infection. Metabolism, 9: 528-550, 1960 .

9. HEYMSFIELD, S.B.; ARTEAGA, C. \& MCMANUS, C.B. - Measurements of muscle mass in humans: validity of the 24-hour urinary creatinine method. Amer. J. clin. Nutr., 37: 478-494, 1983.

10. HEYMSFIELD, S.B.; TIGHE, A. \& WANG, Z.M. - Nutritional assessment by anthropometric and biochemical methods. In: SHILS, M.E.; OLSON, J.A. \& SHIKE, M. Modern nutrition in health and disease. 8. ed. Malvern, PA, Lea \& Febiger, 1994. vol. 1, p. 812-841.

11. KELLY, J.J.; MANGOS, G.; WILLIAMSON, P.M. \& WHITWORTH, J.A. - Cortisol and hypertension. Clin. exp. Pharmacol. Physiol., 25(suppl.): S51-S56, 1998.

12. MARTINI, L.A.; HEILBERG, I.P.; CUPPARI, L. et al - Dietary habits of calcium stone formers. Braz. J. med. biol. Res., 26: 805-812, 1993.
13. MIZOCK, B.A. \& TROGLIA, S. - Nutritional support of the hospitalized patient. Dis Month, 43: 349-426, 1997.

14. PIAMPHONGSANT, T. \& OPHASWONGSE, S. - Treatment of pemphigus. Int. J. Derm., 30: 139-146, 1991.

15. RITZ, P. \& ELIA, M. - The effect of inactivity on dietary intake and energy homeostasis. Proc. Nutr. Soc., 58: 115-122, 1999.

16. SINGER, K.H.; HASHIMOTO, K.; JENSEN, P.J.; MORIOKA, S. \& LAZARUS, G.S. Pathogenesis of autoimmunity in pemphigus. Ann. Rev. Immunol., 3: 87-108, 1985.

17. WAJCHENBERG, B.L.; BOSCO, A.; MARONE, M.M. et al. - Estimation of body fat and lean tissue distribution by dual energy $\mathrm{X}$-ray absorptiometry and abdominal body fat evaluation by computed tomography in Cushing's disease. J. clin. Endocr., 80: 2791-2794, 1995.

18. WELLE, S.; THORNTON, C.; TOTTERMAN, S. \& FORBES, G. - Utility of creatinine excretion in body-composition studies of healthy men and women older than $60 \mathrm{y}$. Amer. J. clin. Nutr., 63: 151-156, 1996.

19. WORLD HEALTH ORGANIZATION - Arterial Hypertension. Expert committee Report. Wld. Hlth. Org. techn. Rep. Ser., (628), 1978.

20. ZILLIKENS, D.; AMBACH, A.; ZENTNER, A. et al. - Evidence for cell-mediated immune mechanisms in the pathology of pemphigus. Brit. J. Derm., 128: 636-643, 1993.

Received: 17 September 1999

Accepted: 03 December 1999 